\title{
Characterization of an Acidification and Equalization Tank (AET) Operating as a Primary Treatment of Swine Liquid Effluent
}

\author{
Fabrício Motteran", Erlon Lopes Pereira and Claudio Milton Montenegro Campos \\ Departamento de Engenharia Agrícola; Universidade Federal de Lavras; C. P: 3037; 37200-000; Lavras - MG; \\ Brasil
}

\begin{abstract}
This work evaluated the potential of the acidification equalization tank (AET) used as a primary treatment unit, treating the hog farming wastewater. The treatment system consisted of a degritter with a triangular-notch weir, for measuring the flow, a static sieve, and an acidification and equalization tank (AET), an anaerobic baffled reactor $(A B R)$, an upflow anaerobic sludge blanket (UASB) reactor, a settling tank, a greenhouse for fertirrigation and two infiltration ponds. The AET had a net capacity of 8,000 liters, internally covered with asphalt blanket, worked based on surface loading rates application. The unit operated continuously, with its flow varying from 0.1 to $10 \mathrm{~L} \mathrm{~s} \mathrm{~s}^{-1}$. To determine the efficiency, the following parameters were measured: $p H ; C O D ; B O D$; volatile and fixed solids; settleable solids; total, intermediate and partial alkalinity and total acidity. The COD removal varied from 5 to 20\%. The average $\mathrm{pH}$ was 7.3 and the total, intermediate and partial alkalinity in the effluent, were 1919, 846, 1197 $m g L^{-1}$, respectively. The total acidity in the effluent was $34 \mathrm{mg} \mathrm{L}^{-1}$. The influent and effluent total BOD and oil \& grease concentrations were 3436 and $3443 \mathrm{mg} \mathrm{L}^{-1}$, and 415 and $668 \mathrm{mg} \mathrm{L}^{-1}$, respectively. It was found that the AET worked properly concerning the acidification, equalization and sedimentation processes, confirming low cost of implementation and easy operation, when compared to other traditional decanters.
\end{abstract}

Key words: Swine effluent, organic matter removal, primary treatment, pollution control, inexpensive technologies

\section{INTRODUCTION}

The swine wastewater causes pollution problems and water contamination in several countries around the world due to its high organic loads, solids and nutrients (Oliveira and Foresti 2004). The pig-producing regions in Brazil in recent years have increased the environmental pollution due to unsustainable practice and lack of planning with appropriate policies of pig farming production. This activity pollutes water, air, soil and provides conflicts with other activities (Pereira et al. 2009; Pereira et al. 2010a). Today, because of recent environmental legislation policies, the producer may be held criminally liable for any damage caused to the environment, human health and animals. All pig farmers must have a rational program of waste control, tending to its proper care to prevent and minimize the pollution problems. This control must be done to stabilize the organic matter through the biological treatment systems, thus reducing the pollution damage (Pereira et al. 2010b). To maintain the physical integrity of the system avoiding the problems in the hydraulic pumps and pipelines of biological treatment process, physical treatments are needed, known as preliminary treatment, carried out by sand retention boxes, screens and grids, capable to

*Author for correspondence: fabriciomotteran@yahoo.com.br 
remove the coarse and abrasives solids. After this step, the liquid effluent is separated from the solids and is sent for the primary treatment. The majority of suspended solids and organic matter are removed from the effluent by decanting in the primary treatment. The effluent at this stage usually contains considerable amount of organic matter and a relatively high $\mathrm{BOD}_{5}$. Pig farmers in small and medium businesses usually employ only preliminary and primary treatment, thus do not comply with the environmental laws for the discharge of effluents into water bodies. In some units used as primary treatment, the biological degradation of organic matter may occur, which increases the effectiveness of the secondary treatment. Among many units used in the primary process, decanters or settling tanks, such as the acidification and equalization tank (AET) are worth mentioning because of the low cost of implementation and operation. However, little attention has been given to this unit due to lack of information regarding its efficiency and operation. The AET exercises functions as equalization, flotation, sedimentation, hydrolysis and acidification of the effluent, which makes this unit essential in the effluent treatment with high concentrated organic matter. Therefore, the objective of this study was to characterize the physical and chemical processes ocurring in the AET in order to better understand its operation, as well as to determine its technical design.

\section{MATERIALS AND METHODS}

The treatment system was operated for 27 weeks in which the effluent from the hog farming was sent directly to the units through open channels. The first unit (primary process) consisted of a sandbox for retention of abrasive materials, especially earth and sand. The effluent was then passed to the static screen in which the liquid and the coarse part were separated and the liquid effluent was sent to the AET of 8,000 liters of net volume, lined with asphalt. This effluent was subsequently sent for the secondary treatment units by means of a Nemo pump (Netzsch), $\eta=78 \%$ and rotations ranging from $239 \mathrm{rpm}$ to WEG $1680 \mathrm{rpm}$. This pump was controlled by a frequency inverter, thus varying the flow accurately, allowing modifying the volumetric organic loading rate. Table 1 shows the physicalchemical parameters analyzed, the analysis frequency and the methodology.

Table 1 - Parameters, frequency of monitoring methodologies and physical-chemical AET.

\begin{tabular}{lll}
\hline Physical-Chemical Parameters & Frequency & Referencies \\
\hline $\mathrm{pH}$ & $2 \times$ week & APHA, AWWA, WPCF (1998) \\
$\begin{array}{l}\text { Total, partial and intermediated alkalinity } \\
\text { Total, suspended and dissolved chemical } \\
\text { oxygen demand (COD) }\end{array}$ & $2 \times$ week & RIPLEY et al. (1986), JENKINS et. al (1983) \\
$\begin{array}{l}\text { Total, suspended and dissolved biochemical } \\
\text { oxygen demand (BOD) }\end{array}$ & weekly & Wincley methodology \\
$\begin{array}{l}\text { Total, suspended and dissolved solids: } \\
\text { fix and volatile }\end{array}$ & weekly & APHA, AWWA, WPCF (1998) \\
$\begin{array}{l}\text { Total Kjeldahl nitrogen (TKN) } \\
\begin{array}{l}\text { Total phosphorus (Total-P) } \\
\text { Total acidity }\end{array}\end{array}$ & $2 \times$ month & APHA, AWWA, WPCF (1998) \\
Electrical conductivity & $2 \times$ month & APHA, AWWA, WPCF (1998) \\
& $2 \times$ week & Potenciometric method (NaOH 0,02N) \\
& $2 \times$ week & APHA, AWWA, WPCF (1998) - Hach \\
\end{tabular}

\section{RESULTS AND DISCUSSION}

Equalization Flow

The effluent flow variation in the AET was measured using the triangular-notch weir intalled inside the degritter unit. The flow ranged from 0.1 to $10 \mathrm{~L} \mathrm{~s}^{-1}$. The flow equalization was essential in order to diminish the operational problems caused by the excess of organic loading rates. The AET allowed the drop of the $\mathrm{pH}$ due to the formation of organic acids caused by the hydrolysis and fermentation processes from the $8^{\text {th }}$ weeks (Fig. 1). However, these values were not significant due to little variation between the value of the unit influent and effluent, especially after the $9^{\text {th }}$ weeks of analysis.

According to von Sperling (2006), the alkalinity of the effluent is mainly influenced by the presence 
of bicarbonate $\left(\mathrm{HCO}_{3}^{-}\right)$, carbonate $\left(\mathrm{CO}_{3}^{-2}\right)$ and hydroxides $\left(\mathrm{OH}^{-}\right)$, usually arranged in the form of alkali and alkaline earth salts. These alkaline earth metals can be easily found in swine foodstuff in the form of minerals such as sodium, potassium, calcium, magnesium, etc. After partial hydrolysis, the formation of intermediate volatile fatty acids, which undergo through the biochemical conversion is common, resulting in the compounds that generate alkalinity, as for example, sodium bicarbonate (Chernicharo 2007).

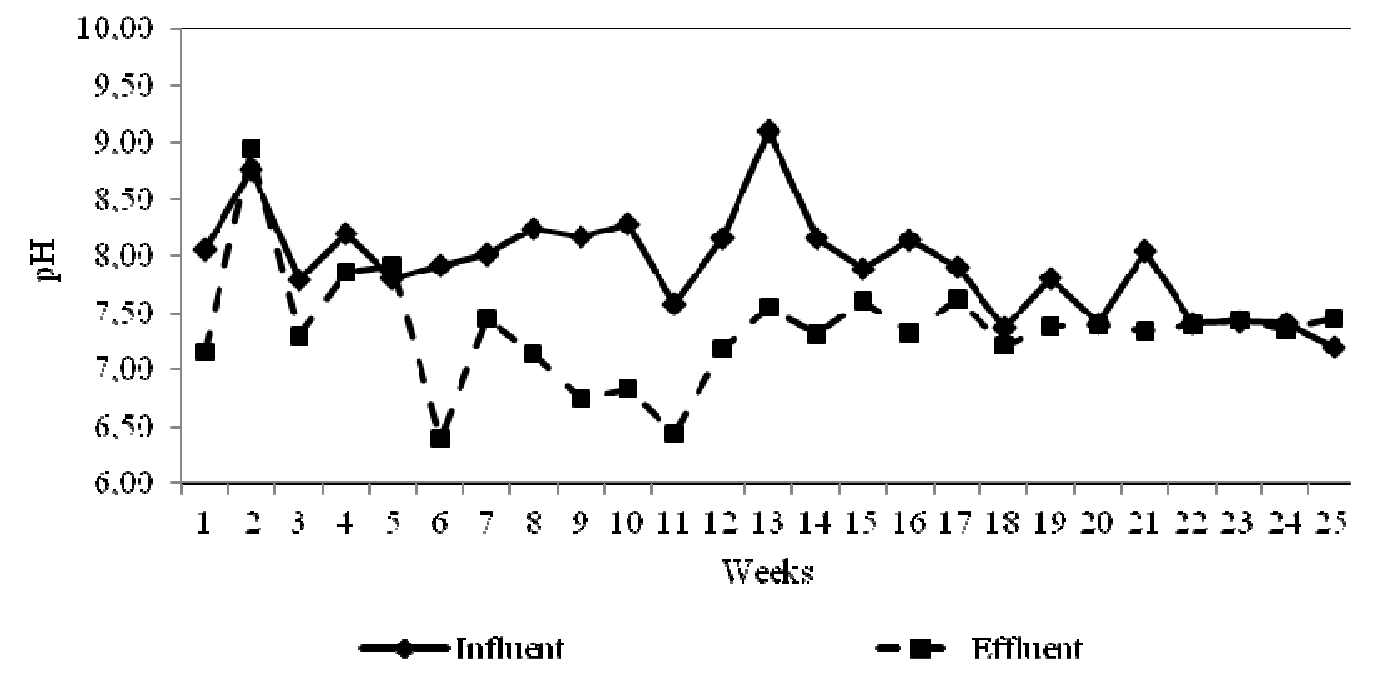

Figure 1 - Variation of $\mathrm{pH}$ in the acidification and equalization tank (AET).

In this study, the values of total acidity of the effluent were always higher than in the influent as observed in Figure 2. The hydrolysis of proteins, nutrients commonly found in pigs' rations, results in amino acids, which may respond biochemically to form ammonia $\left(\mathrm{NH}_{3}\right)$, influencing the alkalinity of the unit. The combination of ammonia and carbonic acid in the solution resulted in the formation of ammonium bicarbonate (Chernicharo 2007), which explained the behavior of the concentration of total, intermediate and partial alkalinity in the effluent $(1919,846$ and $1197 \mathrm{mg}$ $\mathrm{L}^{-1}$, respectively). The degradation of carbohydrates and alcohols does not generate alkalinity, since these are organic compounds that do not lead to the formation of a cation as the final product (Chernicharo 2007). However, these are important compounds, since the degradation of carbohydrates produces high microbial growth that can reduce the alkalinity, as ammonium $\left(\mathrm{NH}_{4}{ }^{-}\right.$ $\left.\mathrm{HCO}_{3}{ }^{-}\right)$is used as a nitrogen source for the biological synthesis, mainly by the autotrophic aerobic bacteria (nitrite-forming bacteria). The concentration of nitrogen present normally exceeds the amount required by the microorganisms to oxidize the carbonaceous matter, hence only the part of the nitrogen is removed by the heterotrophic organisms and incorporated in the microbial biomass (Gray 1992). Even the AET being prior to the biological treatment, with relatively high levels of oxygen, could not remove most of the ammonia nitrogen to the secondary processes of anaerobic treatment. This residual nitrogen, when discharged in the water bodies results in eutrophication, stimulating excess growth of the photoautotrophic microorganisms (Gray 1992). High concentrations of ammonia in the liquid could have ecological implications, regarding the dynamics of dissolved oxygen in biological treatment units, since $4.3 \mathrm{mg}$ of oxygen is required to oxidize $1.0 \mathrm{mg}$ of ammonia. As a result, in the effluents with high BOD, nitrogen can result in oxygen consumption due to nitrification, interfering with the microbial consortium of the treatment system (Prates 1997). Thus, the AET unit used before the secondary treatment system, could assist the anaerobic processes. Figure 2 showed that the composition of the effluent due to hydrolysis and acidification did not need chemicals, indicating the adaptation of the biomass formed in the unit, due to the buffering stability of the IA/PA (Fig. 3). 


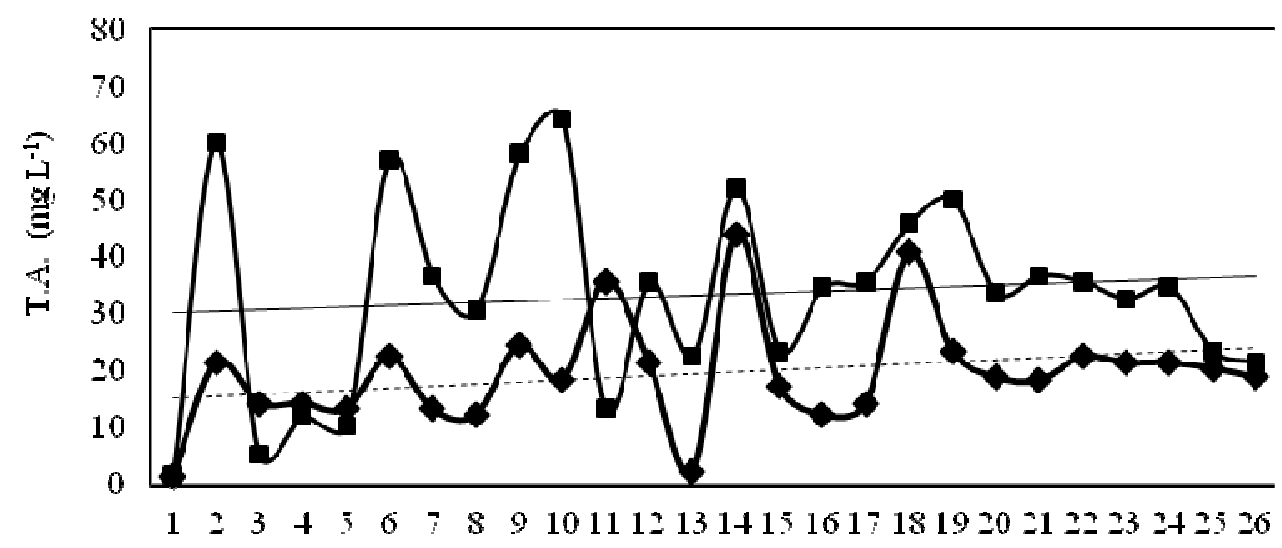

Weeks:

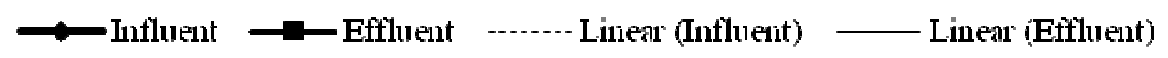

Figure 2 - Total acidity (T.A.) behavior in the AET.

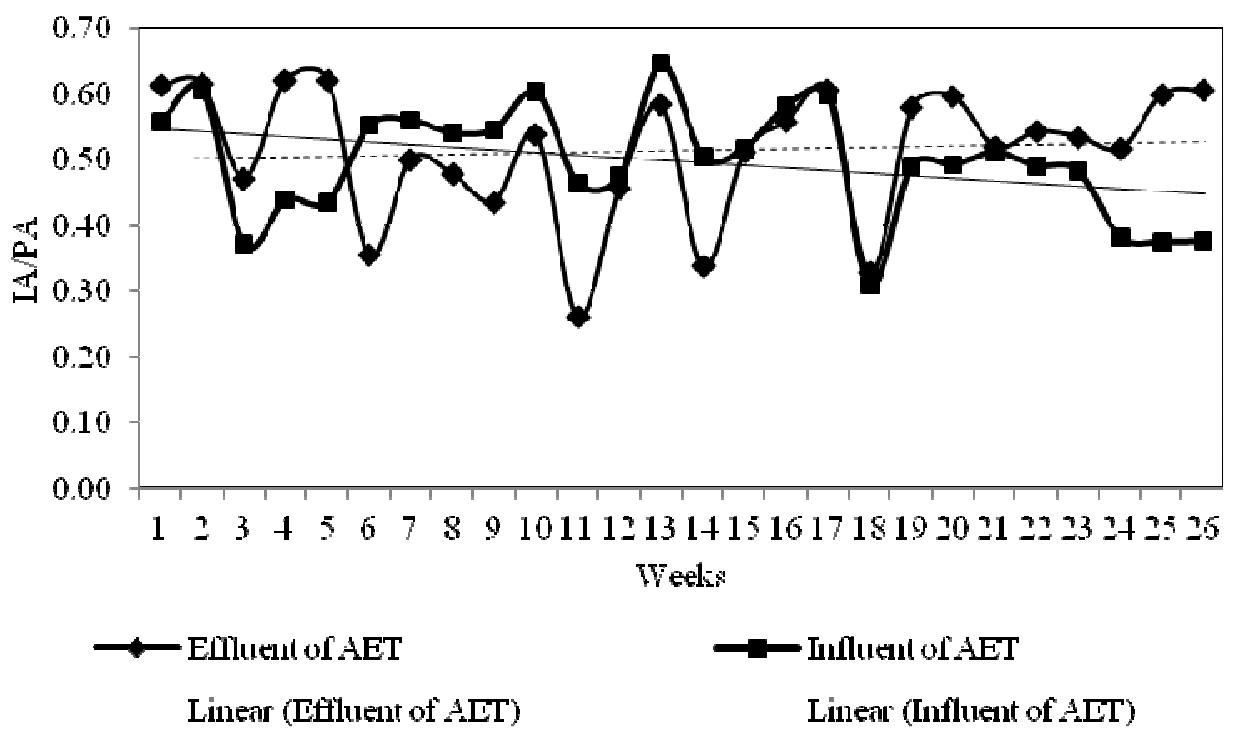

Figure 3 - Ripley relationship (IA/PA) in AET.

\section{Sedimentation}

Sedimentation is a process governed by Stokes law, often used in the wastewater treatment systems, and it is capable of removing the particulate matter from the liquid medium. The AET was operated at different flow rates, depending on the type and characteristics of the influent. Campos et al. (2005a) worked on a laboratory scale with swine effluent and observed the accumulation of solids in the bottom of the AET caused by the excessive hydraulic retention time (HRT). This study also showed that the HRT caused an increase in the concentration of settling solids, which was repressed in the AET (Fig.4).
However, the HRT of the AET was not calculated since the influent was related to swine washing bays, providing a great variation in the input wastewater; on the other hand the output of AET was controlled by a pump that was programmed to provide the HRT of $19 \mathrm{~h}$ for the further treatment. Even without the direct calculation of the HRT, it was observed that this unit was able to settle the solids and performed the hydrolysis of organic matter.

Due to the sedimentation characteristic of the solids, the AET achieved the biomass hydrolysis of complex organic compounds in long runs, thus leading to a considerable $\mathrm{COD}_{\text {total }}$ removal (Table 
2). However, because the solids accumulated in the bottom of this unit, an increase in the effluent $\mathrm{BOD}_{\text {total }}$ in relation to its influent was observed, resulting in negative removal efficiencies, caused by the exit of settling solids. The effluent of the AET was monitored constantly, in order to estimate the amount of sludge that was being retained by the unit. The largest percentage of sludge $(75 \%)$ was related to volatile solids and could be characterized as a good quality sludge hydrolysis and acidification of the medium. Figure 4 shows the concentration of settling solids in the AET.

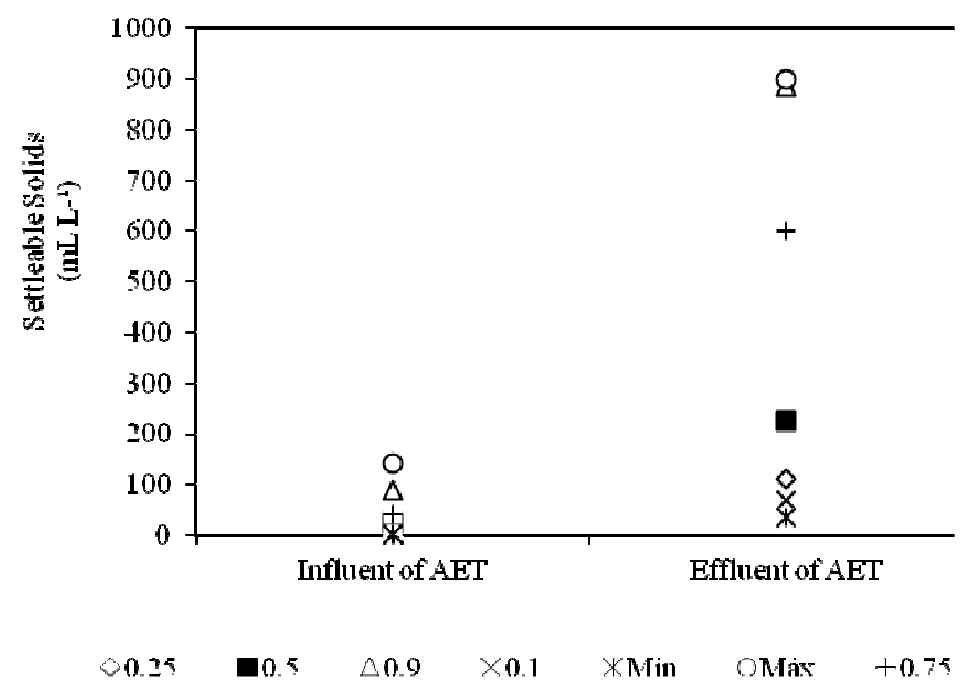

Figure 4 - Settleable solids (S.S.) concentration in AET.

Table 2 - Concentration of fixed and volatile solids.

\begin{tabular}{|c|c|c|c|c|c|c|}
\hline \multirow[b]{2}{*}{ Parameters } & \multicolumn{3}{|c|}{ Influent } & \multicolumn{3}{|c|}{ Effluent } \\
\hline & Total Solids & Total Fix Solids & Total Volatile Solids & Total Solids & Total Fix Solids & Total Volatile Solids \\
\hline Average & 4804,6 & 1676,0 & 3128,3 & 9513,7 & 2377,2 & 7136,6 \\
\hline Minimum & 750,0 & 165,0 & 585,0 & 2660,0 & 791,7 & 1868,3 \\
\hline Maximum & 9898,3 & 7776,7 & 7435,0 & 39360,0 & 7038,3 & 33790,0 \\
\hline V. C. & 0,5 & 1,0 & 0,5 & 1,1 & 0,7 & 1,2 \\
\hline Average & 4804,6 & 1676,0 & 3128,3 & 9513,7 & 2377,2 & 7136,6 \\
\hline Median & 4625,0 & 1223,3 & 2843,3 & 5615,0 & 1730,0 & 3916,7 \\
\hline Geom. average & 4131,0 & 1264,2 & 2677,2 & 6703,3 & 1918,2 & 4725,3 \\
\hline \multicolumn{7}{|l|}{ Variance } \\
\hline S.D. & 2450,9 & 1668,0 & 1703,7 & 10037,6 & 1771,9 & 8447,7 \\
\hline Average - 1 SD. & 2353,7 & 8,0 & 1424,7 & $-523,9$ & 605,2 & $-1311,1$ \\
\hline Average + 1 SD. & 7255,5 & 3344,0 & 4832,0 & 19551,4 & 4149,1 & 15584,3 \\
\hline \multicolumn{7}{|l|}{ Percentage } \\
\hline $10 \%$ & 2246,0 & 708,3 & 1438,0 & 3036,7 & 964,3 & 1976,3 \\
\hline $25 \%$ & 2985,0 & 888,3 & 1838,3 & 3796,7 & 1086,7 & 2750,0 \\
\hline $50 \%$ & 4625,0 & 1223,3 & 2843,3 & 5615,0 & 1730,0 & 3916,7 \\
\hline $75 \%$ & 6181,7 & 1830,0 & 3970,0 & 8698,3 & 3111,7 & 5663,3 \\
\hline $90 \%$ & 7868,7 & 2142,3 & 5026,7 & 20609,7 & 4803,0 & 15219,3 \\
\hline
\end{tabular}

Within the concentration of total solids found in the effluent of AET, the majority were suspended solids (Fig. 5). It was expected that much of the total solids concentration would be presented as filtered or dissolved; however, that was not possible due to the accumulation of the sludge. 


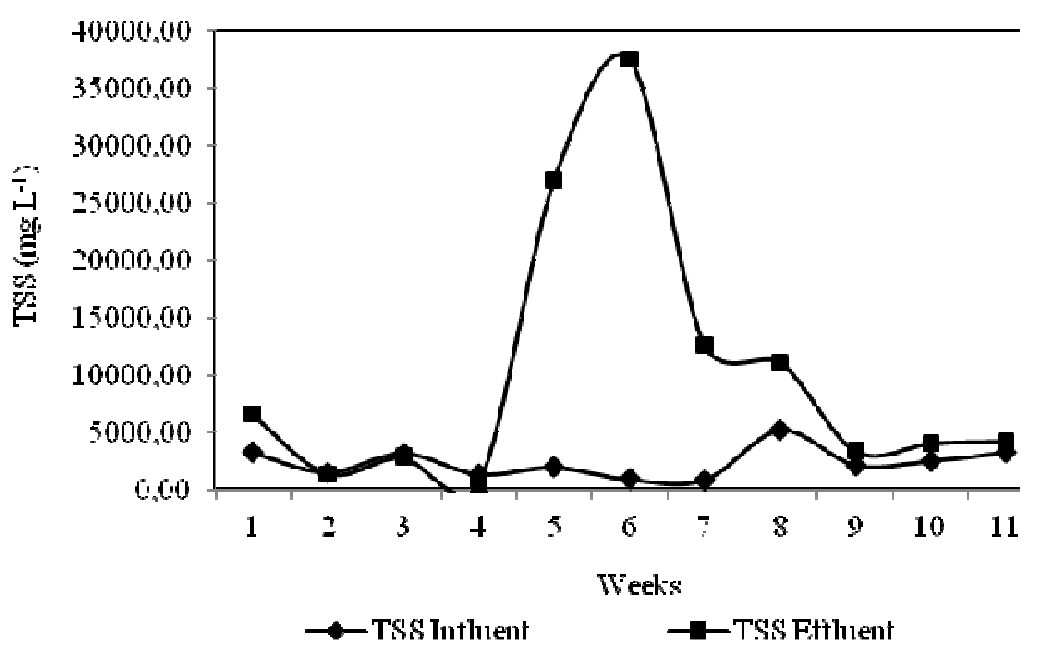

Figure 5 - Total Suspended Solid (TSS) fractions behavior in AET.

\section{Behavior of dissolved fraction}

Even with most of the solids present in the wastewater as suspended, the AET showed good hydrolysis ability. To know the potential of AET in hydrolyzing the solids, the total and dissolved solids (TS-DS) of the influent and effluent were monitored. It was found that $56 \%$ of total solids that flocked in the AET were transformed into dissolved solids. This high efficiency of hydrolysis was due to the adaptation of the biomass and due to the high concentration of suspended solids in the AET. Figure 4 showed that the VDS in the influent of the AET correlated linearly with the concentration of TDS, in which the higher concentration of solids entering the AET turned into it most volatile fraction (Fig. 6). However, observed effluent concentrations of VDS were almost always in the range of 400 to $2000 \mathrm{mg} \mathrm{L}^{-1}$, independent of the concentration of TDS in the effluent, showing that the volatile part was dissolved in the biochemical processes by the biomass present in the AET (Fig. 7). The electrical conductivity (EC) of the effluent is directly related to the concentration of dissolved solids. In this experiment, after several weeks of operation, the EC values tended to stabilize due to the homogenization of the concentration of total dissolved solids in the effluent (Fig. 8). Each week of research is referring to two plotted points on the horizontal axis in Figure 8.

As shown in Figure 7, the concentration of VDS was almost constant in relation to TDS. As a result, the TDS could be expressed as a result of EC, as shown in Equation 1, an important result as this permitted indirect determination of the concentration of VDS passed on the secondary system by the determination of EC, for instance by on-line monitoring.

$\mathrm{VDS}=521,14 \times$ EC Eq. 1

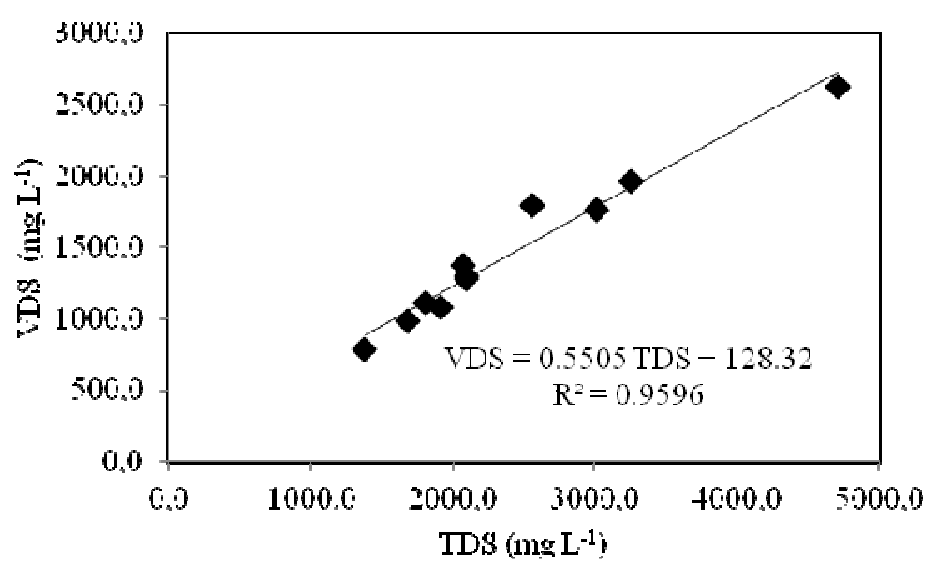

Figure 6 - Relationship between the TDS and VDS in the AET influent. 


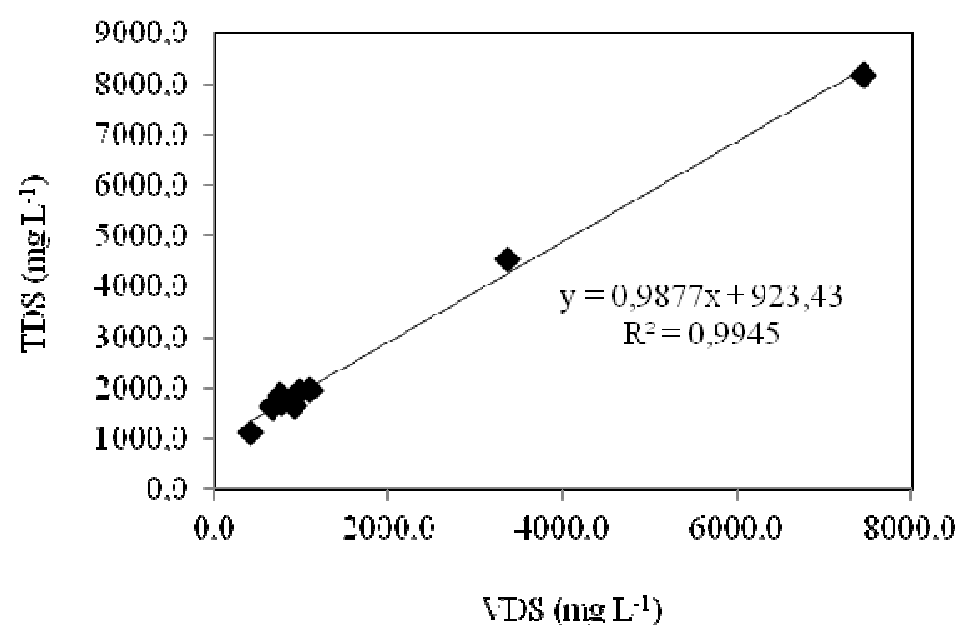

Figure 7 - Relationship between the TDS and VDS in the AET effluent.

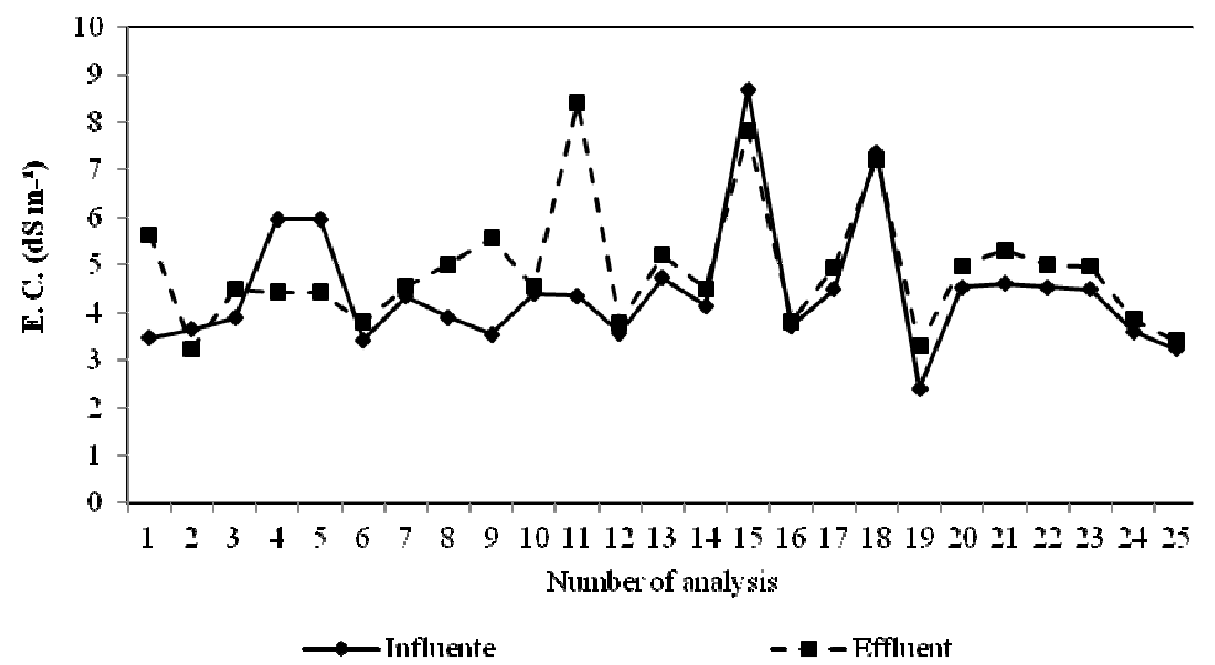

Figure 8 - Influent and effluent electrical conductivity (EC) of the AET.

The relationship between the effluent total filtered BOD and influent total BOD is shown in Figure 9. It was observed that increasing the concentration of total BOD increased the concentration of filtered BOD. The behavior shown in the graphic described the AET that even being subjected to organic and hydraulic shocks, could degrade the total BOD (dissolved + suspended fractions) to produce the filtered BOD. So even if the flowrate in this experiment was kept constant, it was impossible to get in the subsequent reactors a steady-state condition, since the BOD and COD concentrations were always different, as shown in Figures 9 and 10, respectively.

\section{Flotation}

Flotation is an operation used to separate the particles from a less dense liquid phase. The separation can be achieved through the bubbles of biogas. The bubbles attach to particulate matter and the buoyant force of the particles, which combined with the gas, is large enough to allow the particle to float to the surface. The particles that have lower density than the liquid can thus ascend. A similar process occurred in the AET due to the anaerobic process. The main advantage of the flotation over the sedimentation is that very small or light particles, which settle out slowly, can be completely removed over shorter periods of time. Once the particles float to the surface, they can be collected by a withdrawal operation.

In the AET, a great ability to degrade the nitrogen compounds, oils and greases was observed. The latter, which have hydrophobic parts, forms scum on the surface, leaving together with the liquid effluent, resulting in the negative removal 
efficiencies (Fig. 11). The AET showed no incompatibilities for the oils and greases flotation; however, as it was not possible to measure the upward velocity of particles, the same time as for sedimentation was assumed.

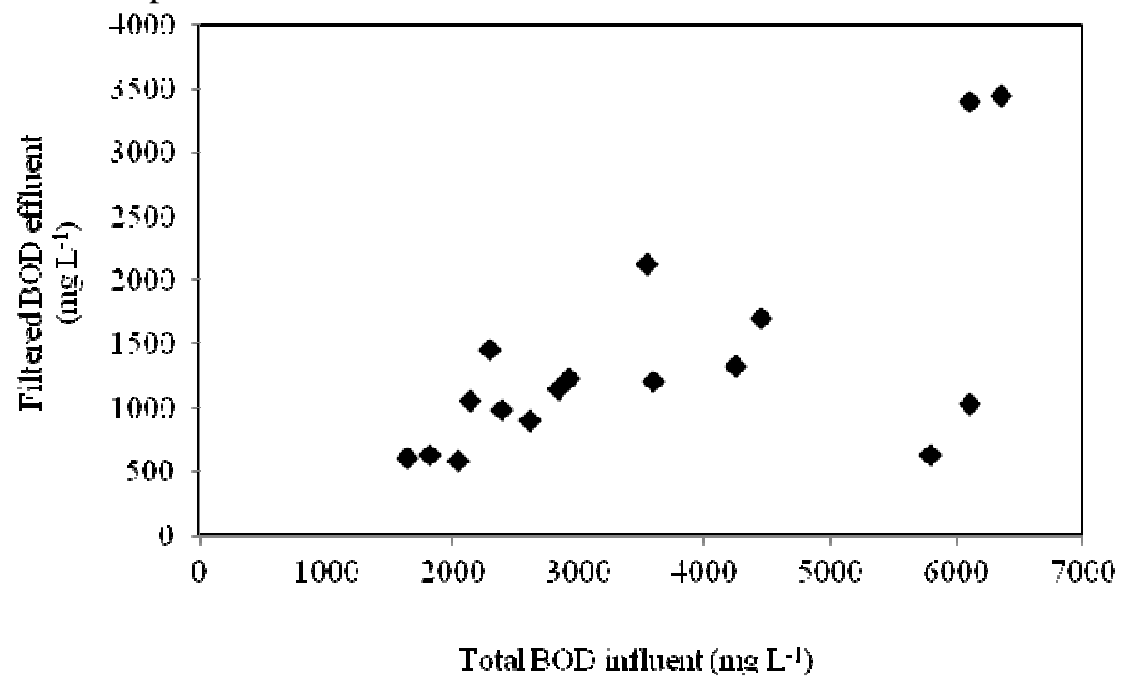

Figure 9 - Relationship between total BOD influent and filtered BOD effluent in the TAE.

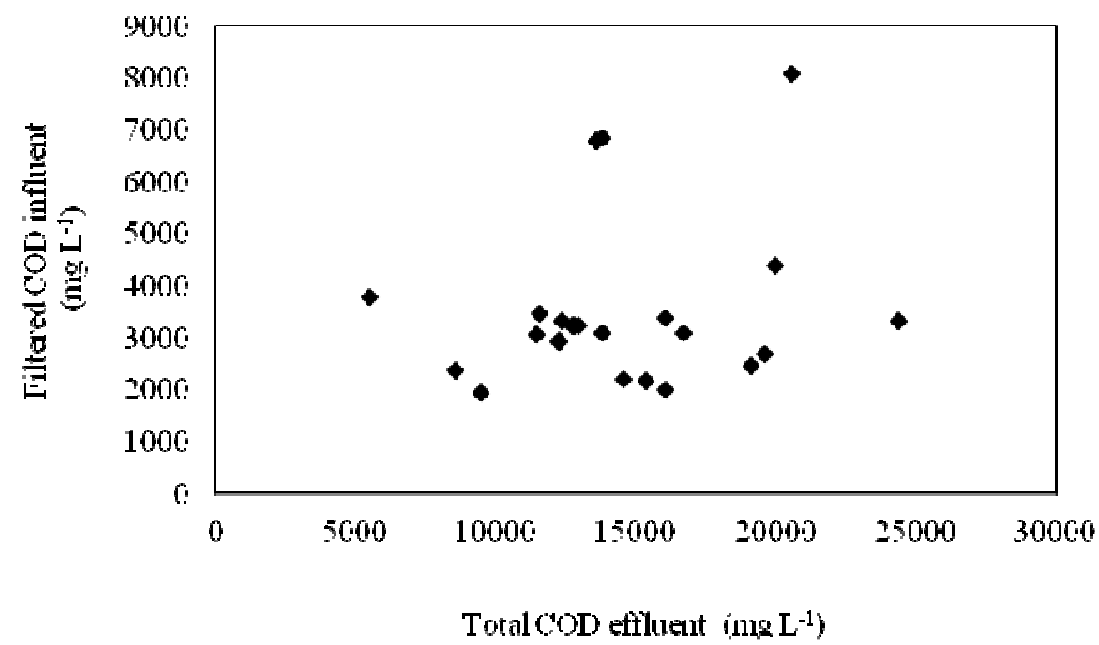

Figure 10 - Relationship of filtered COD influent and total COD effluent.

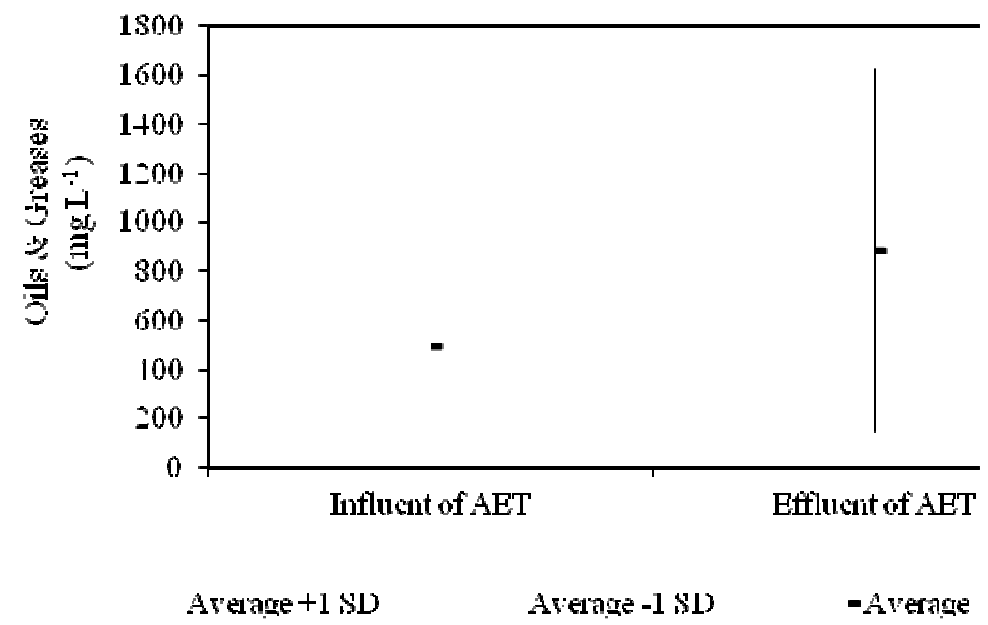

Figure 11 - Concentration range of oil and grease in the influent and effluent of AET. 


\section{Total Nitrogen and Total Phosphorus}

As can be seen in Figure 12, the AET has a low nitrogen removal efficiency. This occurs because the nitrogen compounds, present in the rations, when degraded release nitrogen compounds in the effluent of the AET, thus leaving the total nitrogen concentration in the effluent similar to the concentration in the influent. However, these compounds are presented in a more assimilation form to the bacteria in the subsequent biological units. Since the release of phosphorus occurred according to the acidification, higher levels of phosphorus were observed in the effluent of the AET in the days when the pumping was stopped due to clogging or maintenance. During these days the effluent remained for longer time in the AET, exposed to acidification, producing the effluent with higher acidity and phosphorus concentration (Fig. 13). The gradient of oxygen decrease (anaerobic or anoxic environment) provided phosphorus accumulating through the bacterial secretion. Therefore, this accumulated in the cytoplasm in the form of polyphosphates. This can be used as the energy derived from the hydrolysis of these compounds to apprehend the organic substrates stored as poly-hydroxybutyrate (PHB) and poly-hydroxyvalerate (PHV) used as energy source in aerobic environments. The removal of phosphorus is more efficient in the conditions of alternating aerobic and anaerobic conditions (Osada et al. 1991; Van Haandel and Marais 1999). Campos (1989) reported that the contact of the influent with raw sludge also helped in the predominantly anaerobic removal of phosphorus, which did not occur in the present study due to the sedimentation of organic matter in the AET. The fermentation that occurred in the anaerobic and anoxic environment favored different groups of bacteria, which caused the $\mathrm{pH}$ decrease, solubilizing phosphorus normally present in the mineral form (hydroxyapatite) usually found as a store of calcium and phosphorus in the animals nad afterward eliminated in the waste.

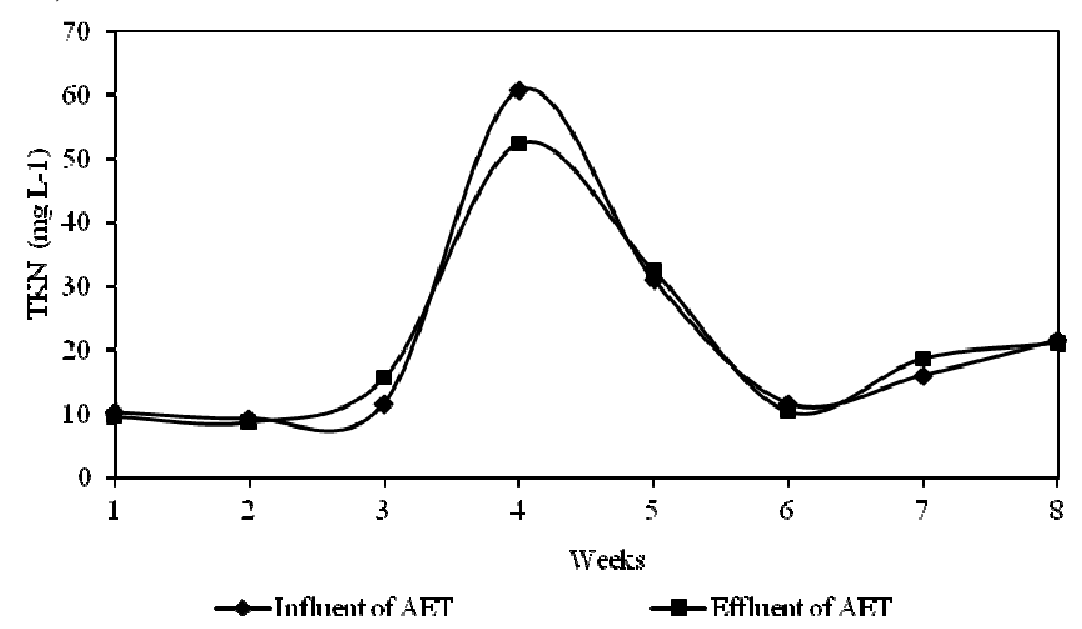

Figure 12 - Total nitrogen concentration in AET.

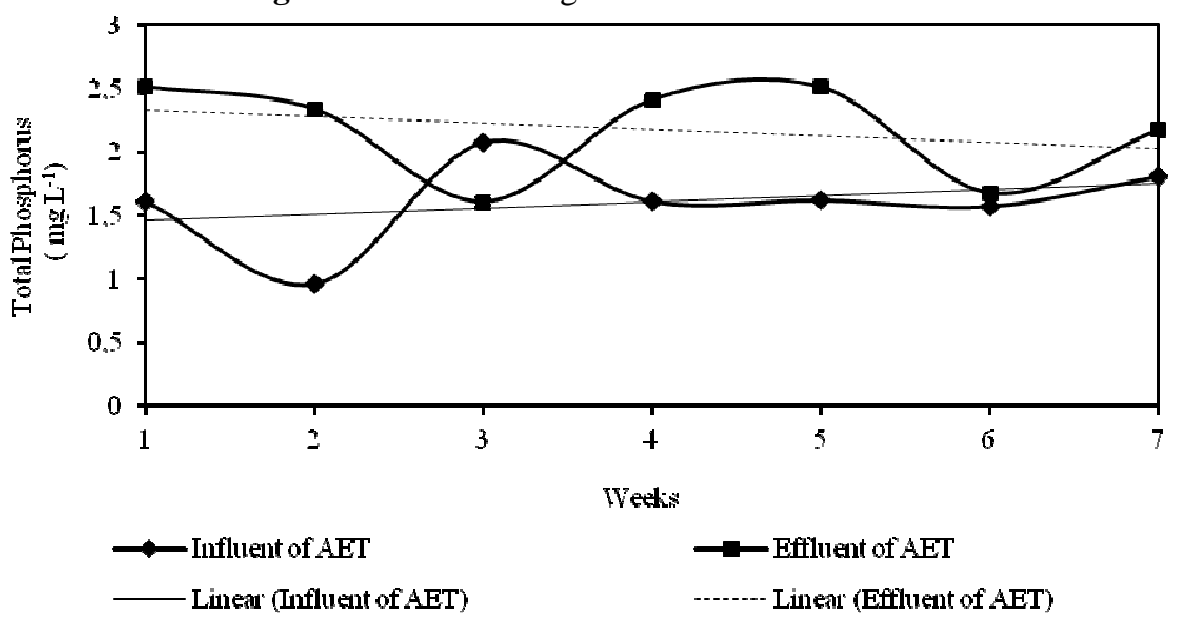

Figure 13 - Total phosphorus concentration in AET. 


\section{CONCLUSION}

The acidification and equalization tank (AET) was efficient to promote uniform effluent concentrations and decreasing the incidences of organic shocks. In addition to standardizing the concentration, the AET was an attractive option to improve the performance of subsequent biological units. The amount of the sludge generated in the bed of the AET unit changed the viscosity of the effluent, reducing the performance of the pump, hence, a constant evaluation of load losses due to thickening of the sludge was needed. It was observed that the inclusion of samplers, in the design of an AET, would be of great importance in order to maintain a better control of the quality and quantity of the sludge formed in this. The sealing of the unit with asphalt blanket was essential to prevent the corrosion caused by the chemical and biological processes. It was observed that the AET used as the primary treatment for solids removal showed satisfactory performance concerning the sedimentation, flocculation, hydrolysis and acidification processes, and also improved the biological treatment process for the secondary units.

\section{ACKNOWLEDGEMENTS}

The authors thank CNPq and FAPEMIG for financial support, also the Water Analysis Laboratory of the Engineering Department of UFLA (LAADEG) for the support in carrying out the physical-chemical analysis.

\section{REFERENCES}

American Public Health Association. Standard methods for the examination of water and wastewater. 20. ed. Washington: AWWA 1162 p.; 1998.

Barber W, Stuckey DC. Nitrogen removal in a modified anaerobic baffled reactor (ABR): 2, Nitrification. Water Res. 2000; 9: 2423-2432.

Boopathy R. Biological treatment of swine waste using anaerobic baffled reactor. Bioresource Technol. 1998; 64: 1-6.

Campos JR. Remoção de DQO e de Nitrogênio em um Sistema de Três Reatores Biológicos de Filme Fixo em Série. Tese de Livre Docência - Escola de Engenharia de São Carlos-USP, p.295. 1989.

Campos CMM, Damasceno, LHS., Mochizuki ET, Botelho, CG. Performance evaluation of a lab-scale upflow anaerobic sludge blanket reactor (UASB) removing organic loading rate from swine manure. Ciênc. Agrotec. 2005a; 29: 848-856.

Campos CMM, Saleh, BB, Carmo, FR. Determination of kinetic parameters of a lab-scale upflow anaerobic sludge blanket reator (UASB) removing organic loading from swine manure effluents. Ciênc. Agrotec. 2005b; 29: 1045-1051.

Campos CMM, Carmo FR, Botelho CG, Costa, CC. Development and operation of an upflow anaerobic sludge blanket reactor (UASB) treating liquid effluent from swine manure in laboratory scale. Ciênc. Agrotec. 2006; 30: 140-147.

Chernicharo CAL. Reatores anaeróbios: princípios do tratamento biológico de águas residuárias. Belo Horizonte: Polytécnica 379 p.; 2007.

Gray NF. Biology of Wastewater Treatment. Oxford University Press: New York, US. 1992.

Osada, T; Haga, K. e Harada,Y. Removal of Nitrogen and Phosphorus from Swine Wastewater by the Activated Sludge units with the Intermittent Aeration Process. Water Res. 1991; 25: 1377-1388.

Pereira EL, Campos CMM, Moterani F. Avaliação do desempenho físico-químico de um reator UASB construído em escala piloto na remoção de poluentes de efluentes de suinocultura. Ambi-Agua. 2010a; 5: 79-88.

Pereira EL, Campos CMM, Moterani F. Effects of pH, acidity and alkalinity on the microbiota activity of an anaerobic sludge blanket reactor (UASB) treating pig manure effluents. Ambi-Agua. 2009; 4: 157-168.

Pereira EL, Campos CMM, Moterani F. Physicalchemical and operational performance of an anaerobic baffled reactor (ABR) treating swine wastewater. Acta. Sci. Technol. 2010b; 32: 399-405.

Prado MAC, Campos CMM. Biogas production in the treatment of Coffea arabica L. processing wastewaters in UASB anaerobic reactor for the potential use in the coffee drying. Ciênc. Agrotec. 2008; 32: 938-947.

Prates KVMC. Verificação da Produção Biológica de Nitrogênio a Partir de Lodos Anaeróbios Granulados Cultivados em Meio Contendo Nitrogênio Amoniacal e Baixas Concentrações de Compostos Orgânicos. (Dissertação de Mestrado). São Carlos, Brasil: Escola de Engenharia de São Carlos - Universidade de São Paulo. 1997.

Van Haandel AC, Marais O. Comportamento do Sistema de Lodo Ativado-Teoria e Aplicação para Projeto e Operação - (ed.) ABES. Campina Grande: Universidade Federal da Paraíba 448p; 1999.

Von Sperling M. Introdução à qualidade das águas e ao tratamento de esgotos: princípios do tratamento biológico de águas residuárias. Belo Horizonte: UFMG 452 p; 2006.

Received: November 01, 2011; Revised: May 09, 2012; Accepted: February 15, 2013 